\title{
Brown Stem Rot Resistance in Soybean Germ Plasm from Central China
}

\author{
M. S. Bachman, Graduate Research Fellow, and C. D. Nickell, Professor of Plant Breeding, Department of Crop \\ Sciences, University of Illinois, Urbana 61801; P. A. Stephens, Pioneer Hi-Bred Int'l., LaSalle, IL 61301; A. D. \\ Nickell, Asgrow Seed Co., Janesville, WI 53546
}

\begin{abstract}
Bachman, M. S., Nickell, C. D., Stephens, P. A., and Nickell, A. D. 1997. Brown stem rot resistance in soybean germ plasm from central China. Plant Dis. 81:953-956.

Soybean accessions from China were screened in an attempt to identify unique sources of resistance to Phialophora gregata, the cause of brown stem rot. In 1994, over 500 accessions from the USDA Soybean Germplasm Collection, University of Illinois, Urbana-Champaign, were evaluated in the field at Urbana, IL, for reaction to brown stem rot. The accessions originated from nine provinces in central China and ranged in maturity from groups II to IV. Disease assessment was based on incidence of foliar symptoms and severity of stem symptoms produced by infection with natural inoculum. Based on field results, 64 putatively resistant lines were selected and evaluated in the greenhouse by a root-dip inoculation method. Thirteen accessions with levels of resistance equal to those of resistant standards were identified from five provinces. These lines may have value as donors of unique sources of resistance to brown stem rot.
\end{abstract}

Brown stem rot (BSR) of soybean, caused by Phialophora gregata (Allington \& D.W. Chamberlain) W. Gams, is an economically important disease in the North Central United States. Gray (5) reported two pathogenic types of the fungus. Type I isolates cause necrosis and defoliation of leaves and vascular discoloration in the stem, whereas type II isolates cause only vascular discoloration. Estimated seed yield reductions of up to $38 \%$ have been reported under conditions that favor disease development $(6,13$, $20,25)$. Host resistance is the primary means of BSR control.

Single dominant genes conditioning resistance to BSR have been identified in soybean accessions originating from Asia. Chamberlain and Bernard (2) conducted BSR evaluations on over 2,000 accessions and identified one resistant strain, PI 84.946-2. This accession was the source of resistance for cvs. BSR 101, BSR 201, BSR 301, BSR 302, and Chamberlain. Genetic studies conducted on lines derived from PI 84.946-2 revealed dominant alleles for resistance at two loci, Rbsl and Rbs3 (3,9). Rbs3 also was identified as the source of resistance in PI 437.970, an accession from northeastern China (26). Gray (8) reported resistance in

Corresponding author: M. S. Bachman

E-mail: bachman@uiuc.edu

Contribution of the Illinois Agricultural Experiment Station.

Research supported in part by the Illinois Soybean Program Operating Board.

Accepted for publication 23 April 1997.

Publication no. D-1997-0527-04R

(C) 1997 The American Phytopathological Society another accession from China, PI 437.823 (later changed to PI 437.833). Subsequent genetic analysis of this accession identified a distinct dominant allele, Rbs2 (9).

Additional resistant soybean lines have been identified, although the relationship between the source of resistance in these lines and $R b s$ loci is unknown. Tachibana and Card (22) confirmed resistance in four accessions initially selected by Chamberlain and Bernard. Waller et al. (24) proposed a resistance mechanism involving several genes in cv. Asgrow A3733, a line unrelated to known sources of resistance. Nelson et al. (14) screened over 3,400 accessions from the USDA Soybean Germplasm Collection, University of Illinois, Urbana-Champaign, and identified putatively resistant types in maturity groups 0 to IV, although none had resistance superior to previously identified sources. Until genetic analyses reveal the source(s) of resistance in these lines, the potential value to breeders may not be realized.

Evaluation of soybean for BSR reaction is difficult in the field due to seasonal and environmental variation $(2,15,25)$, but resistant germ plasm can be identified if uniform symptoms are exhibited (14). A greenhouse screening procedure has been developed that reduces environmental variation found in field studies and is successful in differentiating resistant and susceptible genotypes $(18,19)$. This procedure has been used to identify new sources of resistance and study inheritance of BSR resistance. Sebastian et al. (20) found greenhouse BSR foliar symptoms to be highly correlated with the reactions of soybean lines under field conditions where foliar symptoms appeared on susceptible lines. They found selection in the greenhouse based on foliar symptoms to be useful in identifying soybean lines with field resistance to BSR.
Although resistance to BSR has been identified, pathogenic variability (16) and physiologic specialization $(21,27)$ in $P$. gregata pose a threat to sources of resistance deployed over large areas or for extended periods of time. Current sources of resistance are not immune to infection by $P$. gregata and, in some instances, have been overcome by the pathogen under field conditions $(14,26)$. Thus, there is a need to identify new sources of resistance that can provide yield stability in spite of pathogen variability. Soybean accessions from China are potentially useful sources of resistance to diseases, and cooperative arrangements between the United States and China have provided this type of genetic resource. The objectives of this study were (i) to evaluate 559 Chinese soybean accessions of maturity groups II to IV from the USDA Soybean Germplasm Collection for BSR reaction and (ii) to identify geographic regions in which resistant accessions originated.

\section{MATERIALS AND METHODS}

Soybean accessions (559) originating from nine provinces in central China were obtained from the USDA Soybean Germplasm Collection. The provinces and respective number of accessions were Anhui, 73; Gansu, 48; Hebei, 52; Henan, 94; Jiangsu, 38; Ningxia, 20; Shaanxi, 13; Shandong, 134; and Shanxi, 87. Accessions in maturity groups II to IV were planted in unreplicated plots of four rows that were $3.7 \mathrm{~m}$ long and spaced $76 \mathrm{~cm}$ apart at Urbana, IL, in 1994. BSR foliar symptoms developed during late August and early September (growth stages R5 to R6 [4]), and accessions were scored for disease reaction. BSR foliar incidence was measured as the percentage of plants exhibiting foliar symptoms. Stem symptoms were evaluated on four plants of each accession by splitting stems lengthwise and recording the number of nodes exhibiting necrotic tissue. The stem rating for each accession was the average proportion of infected nodes. Plants with foliar symptoms were selected for stem symptom evaluation if present; otherwise, random plants were chosen. Criteria for selection of resistant types were (i) less than $10 \%$ incidence of foliar symptoms and (ii) fewer than $10 \%$ infected nodes. Sixty-four accessions met these criteria and were subjected to further evaluation in the greenhouse.

Putatively resistant accessions were evaluated in the greenhouse from October 1994 through May 1996, using the root-dip inoculation method of Willmot and Nickell 
(26). Sixty-four accessions and three susceptible and three resistant standards were replicated six times in a randomized complete-block design. Blocks were evaluated sequentially due to greenhouse space limitations. The three resistant standards were L78-4094 (Rbs 1 selection from the cv. Beeson $\times$ [cv. Clark $\times$ PI 84946-2] cross [10, 17]), PI 437833 (Rbs2), and PI 437970 (Rbs3). The three susceptible standards were cvs. Century 84 (23), Resnik (12), and Flyer (11), all of which had susceptible responses to BSR in previous field studies. Susceptible standards were selected from maturity groups II through IV to correspond to the maturities of the accessions evaluated. Entries were inoculated with a monoconidial type I isolate (5) of $P$. gregata, $\mathrm{PgOh} 2$ (obtained from L. Gray, USDA-ARS, University of Illinois, Urbana-Champaign).

Cultures of $P$. gregata were grown by transferring three agar plugs $\left(\sim 2.7 \mathrm{~cm}^{3}\right)$ containing hyphal tips of an active culture from soybean stem agar minimal medium (1) to $100 \mathrm{ml}$ of soybean seed broth $(100 \mathrm{~g}$ of soybean seed per liter of water steamed, strained, and autoclaved). Both stem agar and seed broth were made from susceptible standard Century 84 . Stationary liquid cultures were incubated at $24^{\circ} \mathrm{C}$ in the dark. After 5 weeks, seed broth cultures of $P$. gregata were ground for $75 \mathrm{~s}$ in a blender at high speed. The concentration of mycelial fragments and conidia was determined with a hemacytometer; mycelial fragments of all sizes were included in counts. Ground cultures were diluted with distilled water to a concentration of $1.2 \times 10^{6}$ propagules per $\mathrm{ml}$. Carboxymethyl cellulose was added to the suspension at a rate of $7.5 \mathrm{~g} /$ liter to act as a sticking agent. Seed was germinated in commercial grade sand in 10-cmdiameter plastic pots and grown for 17 days (V1 growth stage [4]) at temperatures ranging from 18 to $24^{\circ} \mathrm{C}$. Sand was rinsed from the roots of 17-day-old seedlings. Five uniform, apparently healthy seedlings were selected, and their roots were blotted dry with paper towels and dipped in a beaker containing $50 \mathrm{ml}$ of a suspension of mycelial fragments and conidia. The seedlings were removed from the inoculum and placed in a 6- to 8-cm depression in a steam-treated $1: 1 \mathrm{sand} /$ sandy-clay-loam-soil mixture that filled a 15-cm-diameter steam-sterilized clay pot. The remaining inoculum was poured over the roots of the five seedlings, and the roots were covered with the sand/soil mixture to a level $\sim 1 \mathrm{~cm}$ below the cotyledons.

Plants were maintained under a 14-h photoperiod at an average nighttime temperature of $18^{\circ} \mathrm{C}$ and an average daytime temperature of $24^{\circ} \mathrm{C}$. Watering regimes varied due to greenhouse space limitations. All entries in four of six blocks received $150 \mathrm{ml}$ of water twice daily from automatic irrigation. All entries in two of six blocks received $300 \mathrm{ml}$ of water once daily by hand. Pots were fertilized weekly with $150 \mathrm{ml}$ of a nutrient solution containing $0.121 \mathrm{~g}$ of $\mathrm{N}, 0.112 \mathrm{~g}$ of $\mathrm{P}, 0.107 \mathrm{~g}$ of $\mathrm{K}$, $0.000044 \mathrm{~g}$ of B, $0.00022 \mathrm{~g}$ of chelated $\mathrm{Fe}$, and $0.00011 \mathrm{~g}$ of chelated $\mathrm{Cu}, \mathrm{Mn}$, and $\mathrm{Zn}$.

Plants were evaluated for BSR reaction after 8 to 9 weeks (R1 to R3 growth stages [4]). Individual pots were rated for incidence of foliar (percentage of plants with foliar symptoms) and stem symptoms. Stem symptoms were measured by splitting each stem lengthwise and recording the height of stem browning (measured in nodes) as a fraction of the total height (measured in nodes). Stem ratings were averaged for all five plants per pot and recorded as a single

Table 1. Brown stem rot (BSR) ratings for putatively resistant Chinese soybean accessions, resistant standards, and susceptible standard cultivars

\begin{tabular}{|c|c|c|c|c|c|c|c|c|c|}
\hline & \multirow[b]{2}{*}{$\begin{array}{c}\text { Maturity } \\
\text { group }\end{array}$} & \multirow[b]{2}{*}{$\begin{array}{c}\text { Province } \\
\text { of origin }\end{array}$} & \multicolumn{2}{|c|}{ Greenhouse 1994-1996 } & & \multirow[b]{2}{*}{$\begin{array}{c}\text { Maturity } \\
\text { group }\end{array}$} & \multirow[b]{2}{*}{$\begin{array}{l}\text { Province } \\
\text { of origin }\end{array}$} & \multicolumn{2}{|c|}{ Greenhouse 1994-1996 } \\
\hline & & & $\begin{array}{c}\text { Foliar } \\
\text { incidence }^{\mathrm{a}}\end{array}$ & $\begin{array}{c}\text { Stem } \\
\text { symptoms }^{b}\end{array}$ & & & & $\begin{array}{c}\text { Foliar } \\
\text { incidence }^{\mathrm{a}}\end{array}$ & $\begin{array}{c}\text { Stem } \\
\text { symptoms }^{\mathrm{b}}\end{array}$ \\
\hline Accession & & & & & PI 567296B & IV & Gansu & 0.00 & $0.01 *$ \\
\hline PI 567323A & II & Gansu & 0.00 & $0.03 *$ & PI 567318 & IV & Gansu & 0.57 & 0.50 \\
\hline PI 567480B & II & Hebei & 0.43 & 0.37 & PI 567333A & IV & Gansu & 0.00 & $0.07 *$ \\
\hline PI 567504 & II & Hebei & 0.69 & 0.52 & PI 567381A & IV & Shaanxi & 0.10 & $0.14^{*}$ \\
\hline PI 567507A & II & Hebei & 0.31 & 0.45 & PI 567419A & IV & Shanxi & 0.62 & 0.66 \\
\hline PI 567537 & II & Shandong & 0.33 & 0.31 & PI 567429D & IV & Shanxi & 0.10 & 0.32 \\
\hline PI 567586A & II & Shandong & 0.35 & 0.28 & PI 567445B & IV & Shanxi & 0.77 & 0.71 \\
\hline PI 567595A & II & Shandong & 0.47 & 0.34 & PI 567516B & IV & Hebei & 0.53 & 0.61 \\
\hline PI 567753A & II & Jiangsu & 0.27 & 0.35 & PI 567523 & IV & Shandong & 0.03 & $0.11^{*}$ \\
\hline PI 567770A & II & Jiangsu & 0.97 & 0.60 & PI 567535A & IV & Shandong & 0.47 & 0.41 \\
\hline PI 567771A & II & Jiangsu & 0.53 & 0.32 & PI 567535B & IV & Shandong & 0.08 & $0.09 *$ \\
\hline PI 567362B & III & Ningxia & 0.23 & 0.38 & PI 567542 & IV & Shandong & 0.03 & $0.10^{*}$ \\
\hline PI 567404A & III & Shaanxi & 0.27 & 0.26 & PI 567544 & IV & Shandong & 0.03 & $0.06^{*}$ \\
\hline PI 567418C & III & Shanxi & 0.90 & 0.70 & PI 567546 & IV & Shandong & 0.07 & $0.09 *$ \\
\hline PI 567479 & III & Shanxi & 0.00 & $0.05^{*}$ & PI 567552 & IV & Shandong & 0.00 & $0.07 *$ \\
\hline PI 567493 & III & Hebei & 0.73 & 0.63 & PI 567567 & IV & Shandong & 0.53 & 0.49 \\
\hline PI 567496 & III & Hebei & 0.43 & 0.52 & PI 567569 & IV & Shandong & 0.33 & 0.45 \\
\hline PI 567497 & III & Hebei & 0.60 & 0.60 & PI 567571 & IV & Shandong & 0.10 & 0.24 \\
\hline PI 567498 & III & Hebei & 0.40 & 0.24 & PI 567583C & IV & Shandong & 0.17 & 0.31 \\
\hline PI 567510A & III & Hebei & 0.90 & 0.74 & PI 567591 & IV & Shandong & 0.23 & 0.14 \\
\hline PI 567511 & III & Hebei & 0.17 & 0.22 & PI 567603B & IV & Shandong & 0.20 & 0.37 \\
\hline PI 567526 & III & Shandong & 0.37 & 0.48 & PI 567605 & IV & Shandong & 0.55 & 0.40 \\
\hline PI 567529 & III & Shandong & 0.97 & 0.69 & PI 567606 & IV & Shandong & 0.60 & 0.69 \\
\hline PI 567541C & III & Shandong & 0.33 & 0.38 & PI 567607B & IV & Shandong & 0.16 & 0.21 \\
\hline PI 567543C & III & Shandong & 0.67 & 0.49 & PI 567614D & IV & Henan & 0.80 & 0.67 \\
\hline PI 567545 & III & Shandong & 0.20 & 0.18 & PI 567615 & IV & Henan & 0.07 & $0.14 *$ \\
\hline PI 567563B & III & Shandong & 0.77 & 0.68 & PI 567749B & IV & Jiangsu & 0.13 & 0.19 \\
\hline PI 567574A & III & Shandong & 0.51 & 0.61 & PI 567762A & IV & Jiangsu & 0.40 & 0.50 \\
\hline PI 567574B & III & Shandong & 0.20 & 0.21 & & & & & \\
\hline PI 567583A & III & Shandong & 0.30 & 0.25 & Standard $^{\mathrm{c}}$ & & & & \\
\hline PI 567583B & III & Shandong & 0.83 & 0.68 & L78-4094 (Rbs1) & II & & 0.07 & 0.15 \\
\hline PI 567585B & III & Shandong & 0.29 & 0.29 & PI $437833(R b s 2)$ & I & & 0.18 & 0.22 \\
\hline PI 567586B & III & Shandong & 0.29 & 0.42 & PI $437970(R b s 3)$ & II & & 0.10 & 0.08 \\
\hline PI 567609 & III & Shandong & 0.07 & $0.11 *$ & Century $84(\mathrm{~S})$ & II & & 0.87 & 0.76 \\
\hline PI 567618A & III & Henan & 0.13 & 0.15 & Resnik (S) & III & & 0.60 & 0.49 \\
\hline PI 567290A & IV & Shanxi & 0.30 & 0.22 & Flyer (S) & IV & & 0.33 & 0.41 \\
\hline PI 567291 & IV & Shanxi & 0.60 & 0.52 & LSD (0.05) & & & 0.22 & 0.27 \\
\hline
\end{tabular}

${ }^{\text {a }}$ Proportion of plants exhibiting brown stem rot foliar symptoms.

b Proportion of total nodes exhibiting internal stem browning. * indicates mean is significantly lower than for the susceptible standards.

${ }^{c} R b s 1, R b s 2$, and Rbs3 are BSR-resistance genes in soybean lines L78-4094, PI 437833, and PI 437970, respectively. S = susceptible. 
observation. To reduce misclassification of BSR-resistant types exhibiting foliar chlorosis or necrosis due to nutrient deficiency or powdery mildew infection, leaf symptoms were recorded only for those plants showing BSR stem symptoms (9).

Greenhouse data collected from six replications over 2 years were subjected to an analysis of variance. A least significant difference test at $P=0.05$ was used to test differences in foliar and stem symptom ratings between lines. Accessions were classified as resistant if the foliar incidence and stem symptom means were (i) significantly lower than the corresponding means of the susceptible standards and (ii) not significantly different from the corresponding means of the resistant standards. Resistant accessions were each traced to a specific province of origin in China in an attempt to identify geographic regions associated with BSR resistance.

\section{RESULTS AND DISCUSSION}

Initial selection of 64 BSR-resistant types (accessions exhibiting less than 10\% foliar incidence and fewer than $10 \%$ discolored nodes) was based on 1994 field data. Further selection was based on greenhouse data collected between 1994 and 1996. Of the 64 accessions, 13 were classified as resistant, with foliar incidence means $\leq 0.11$ and stem symptom means $\leq 0.14$ (Table 1). Although no accessions were immune to BSR, there was no significant difference between foliar and stem symptom means of selected accessions and resistant standards.

The susceptible standards used to evaluate putatively resistant accessions in the greenhouse exhibited a wide range of susceptibility to BSR. Cvs. Century 84, Resnik, and Flyer had significantly different means for BSR foliar incidence: Century 84 had significantly higher foliar and stem symptom means than both Resnik and Flyer (Table 1). Subsequent BSR field evaluations (data not included) indicated that Century 84 was highly susceptible, whereas neither Resnik nor Flyer had disease symptom means significantly greater than resistant standards. This data indicates there may be degrees of susceptibility among these cultivars. This variation among susceptible cultivars may be attributable to differences in genetic background, physiological age, or reaction to the isolate of $P$. gregata used in this study. Waller et al. (24) and Eathington et al. (3) suggested that genes exist that modify a resistant or susceptible reaction to BSR conditioned by the presence or absence of a major gene. The presence of a modifier gene with a small resistant effect in an otherwise susceptible genetic background might produce the reaction seen in susceptible standards Resnik and Flyer.

A second possible explanation for the differing degrees of susceptibility in the standard cultivars is the difference in the relative physiological ages of the three sus- ceptible genotypes. Gray (7) found that BSR disease progression depends on the physiological rather than the chronological age of the plant, and the plant appears to be more susceptible when it approaches reproductive development. Therefore, genotypes of group II maturity would be expected to exhibit BSR symptoms sooner after infection than genotypes of group IV maturity, assuming the same relative degree of susceptibility and chronological age. Symptom expression, therefore, would decrease with increasing length of maturity, given a finite amount of time for disease development. However, this theory is inconsistent with data collected from greenhouse evaluations that indicated highly susceptible reactions for some accessions of maturity group IV (Table 1). Despite the wide range in susceptibility of these standards, resistant types with significantly lower BSR symptom means were identified in the greenhouse.

Another explanation for the degrees of susceptibility in the standard cultivars is a differential response to the isolate of $P$. gregata used in this evaluation. Both pathogenic variability (16) and physiologic specialization $(21,27)$ have been documented in $P$. gregata. Interactions between cultivar and isolate could be responsible for the observed differences in susceptibility among the standards.

The 13 resistant accessions include 1 in maturity group II, 2 in maturity group III, and 10 in maturity group IV (Table 1 ). The resistant accessions originated from five provinces in central China, with 7 of 13 from Shandong Province. The geographic concentration of resistant accessions in Shandong Province may be attributed to collection of genetically related types. This hypothesis is supported by physical and physiological similarities among five of the seven resistant accessions: PI 567523, PI 567535B, PI 567542, PI 567546, and PI 567552, each has white flowers, gray pubescence, buff hilum, group IV maturity, and resistance to Phytophthora races 1 and 7. No other information is available on the pedigree of these lines.

Sebastian and Nickell (18) found that BSR screening can be effective if sources of experimental error are controlled through the use of greenhouse evaluation. Nelson et al. (14) stated that although variation in BSR expression made evaluation of BSR resistance difficult in the field, results from locations with foliar symptoms agreed with results from greenhouse evaluation. They also stated that consistent foliar symptoms were present at only one of multiple locations and that results from that location agreed more closely with greenhouse results than with any other field location. Therefore, field selection in 1994 combined with greenhouse selection between 1994 and 1996 should have been successful in eliminating susceptible genotypes.

Data collected from the field evaluation in 1994 indicated that 64 of 559 accessions were resistant to BSR. Greenhouse evaluation, however, indicated that BSR foliar and stem symptom means of nearly $80 \%$ (51 of 64) of the putatively resistant accessions were not significantly different from the susceptible standards. Subsequent field tests at three locations in 1995 and five locations in 1996 failed to detect significant differences between resistant and susceptible standards and, thus, are not included in the data analysis. These observations support the conclusions drawn from previous experiments that BSR field evaluation of soybean lines can be misleading or difficult to achieve due to high environmental variation. Greenhouse evaluation can and should be used, therefore, to complement field testing as a means of identifying BSR-resistant germ plasm.

\section{LITERATURE CITED}

1. Allington, W. B., and Chamberlain, D. W. 1948 Brown stem rot of soybean. Phytopathology 38:793-802.

2. Chamberlain, D. W., and Bernard, R. L. 1968. Resistance to brown stem rot in soybeans. Crop Sci. 8:728-729.

3. Eathington, S. R., Nickell, C. D., and Gray, L. E. 1995. Inheritance of brown stem rot resistance in soybean cultivar BSR 101. J. Hered. 86:55-60.

4. Fehr, W. R., Caviness, C. E., Burmood, D. T. and Pennington, J. S. 1971. Stage of development descriptions for soybeans, Glycine max (L.) Merrill. Crop Sci. 11:929-931.

5. Gray, L. E. 1971. Variation in pathogenicity of Cephalosporium gregatum isolates. Phytopathology 61:1410-1411.

6. Gray, L. E. 1972. Effect of Cephalosporium gregatum on soybean yield. Plant Dis. Rep. 56:580-581.

7. Gray, L. E. 1974. Role of temperature, plant age, and fungus isolate in the development of brown stem rot in soybeans. Phytopathology 64:94-96.

8. Gray, L. E. 1985. Brown stem rot of soybean. Pages 598-601 in: World Soybean Res. Conf. 3 Proc. R. M. Shibles, ed. Westview Press, Boulder, CO.

9. Hanson, P. M., Nickell, C. D., Gray, L. E., and Sebastian, S. A. 1988. Identification of two dominant genes conditioning brown stem rot resistance in soybean. Crop Sci. 28:41-43.

10. Johnson, H. W. 1958. Registration of soybean varieties, VI. Agron. J. 50:690-691.

11. McBlain, B. A., Fioritto, R. J., and St. Martin, S. K. 1990. Registration of 'Flyer' soybean. Crop Sci. 30:425.

12. McBlain, B. A., Fioritto, R. J., and St. Martin, S. K. 1990. Registration of 'Resnik' soybean. Crop Sci. 30:424-425.

13. Mengistu, A., and Grau, C. R. 1987. Seasonal progress of brown stem rot and its impact on soybean productivity. Phytopathology 77:15211529.

14. Nelson, R. L., Nickell, C. D., Orf, J. H., Tachibana, H., Gritton, E. T., Grau, C. R., and Kennedy, B. W. 1989. Evaluating soybean germ plasm for brown stem rot resistance. Plant Dis. 73:110-114.

15. Nicholson, J. F., Sinclair, J. B., and Thapliyal, P. N. 1973. The effect of rate of planting on incidence of brown stem rot in soybean. Plant Dis. Rep. 57:269-271.

16. Phillips, D. V. 1973. Variation in Phialophora gregata. Plant Dis. Rep. 57:1063-1065.

17. Probst, A. H., Laviolette, F. A., Athow, K. L., and Wilcox, J. R. 1969. Registration of Beeson soybeans. Crop Sci. 9:523-524.

18. Sebastian, S. A., and Nickell, C. D. 1985 . In- 
heritance of brown stem rot resistance in soybeans. J. Hered. 76:194-198.

19. Sebastian, S. A., Nickell, C. D., and Gray, L. E. 1985. Efficient selection for brown stem rot resistance in soybeans under greenhouse screening conditions. Crop Sci. 25:753-757.

20. Sebastian, S. A., Nickell, C. D., and Gray, L. E. 1986. Relationship between greenhouse and field ratings for brown stem rot reaction in soybean. Crop Sci. 26:665-667.

21. Sills, G. R., Gritton, E. T., and Grau, C. R. 1991. Differential reactions of soybean genotypes to isolates of Phialophora gregata. Plant Dis. 75:687-690.

22. Tachibana, H., and Card, L. C. 1972. Brown stem rot resistance and its modification by soybean mosaic virus in soybeans. Phytopathology 62:1314-1317.

23. Walker, A. K., Schmitthenner, A. F., and Fioritto, R. J. 1986. Registration of 'Century 84' soybean. Crop Sci. 26:199-200.

24. Waller, R. S., Nickell, C. D., Drzycimski, D. L., and Miller, J. E. 1991. Genetic analysis of the inheritance of brown stem rot resistance in the soybean cultivar Asgrow A3733. J. Hered. 82:412-417.

25. Weber, C. R., Dunleavy, J. M., and Fehr, W. R 1966. Influence of brown stem rot on agronomic performance of soybeans. Agron. J. 258: 519-520.

26. Willmot, D. B., and Nickell, C. D. 1989. Genetic analysis of brown stem rot resistance in soybean. Crop Sci. 29:672-674.

27. Willmot, D. B., Nickell, C. D., and Gray, L. E. 1989. Physiologic specialization of Phialophora gregata on soybean. Plant Dis. 73:290-294. 